\title{
Critical Factors of CSR in India: An Empirical Evaluation
}

\section{Rupal Tyagi, A.K. Sharma* and Vijay Agrawal}

Research Scholar, the Department of Management Studies, Indian Institute of Technology Roorkee, Roorkee (Uttarakhand) India.

rt.iitdoms@gmail.com

Associate Professor, the Department of Management Studies, Indian Institute of Technology Roorkee, Roorkee. (Uttarakhand) India.

aanilkssharma@gmail.com

Team Leader, Service Ops Tech Lab CoC, McKinsey \& Company, Gurgoan. (Haryana) India.

vijay agrawal@mckinsey.com

${ }^{*}$ Corresponding Author

\begin{abstract}
The past two decades have witnessed a remarkable change in the way businesses run and operate. Profit maximization is no longer remains the focus of businesses. The turn of events has pressurized firms to put serious efforts into a wide range of social responsibility activities and thus shift the corporate goals from socio - economic focus towards increasing shareholder value to the welfare of all stakeholders. The present study determines critical CSR factors that may influence the business and strategic decisions for the Indian corporations using survey instrument. Factor Analysis, one way ANOVA and Descriptive statistics were used for the analysis. The study reports that 'Financial Health, Competency and Stakeholders' are the basic pillars of every organization.
\end{abstract}

\section{Indexing terms/Keywords}

Corporate Social Responsibility, Financial Performance, Competitive Advantage, Stakeholders, India, Business Strategy Academic Discipline And Sub-Disciplines

Management, Sociology and Business.

\section{SUBJECT CLASSIFICATION}

Management

\section{TYPE (METHOD/APPROACH)}

Survey/Interview, Staistical Analysis

\section{Council for Innovative Research}

Peer Review Research Publishing System

Journal: International Journal of Management \& Information Technology

\author{
Vol.4, No.3 \\ editor@cirworld.com \\ www.cirworld.com, member.cirworld.com
}




\section{INTRODUCTION AND PROBLEM STATEMENT}

A wave of soul seeking among practitioners and academicians has been elicited by the overwhelming magnitude of recent corporate outrages (Kashyap et al. 2004). There is a noteworthy descent in ethical behavior. To realize the consequences of such conduct, a pursuit of alternative research is being carried on worldwide. The interest of business to exist may drive an individual to think about the role of business that is in the middle of the debate of the greater good and possible harm (Singh, 2010).

The corporate performance whether a success or failure is now being also judged by their stakeholders - shareholders, analysts, investors, consumers, regulators, activists, labor unions, employees, community organizations and news media. Thus, firms need to do better in non-fiscal domains such as human rights, environment, corporate contributions, community development, and workplace issues. Increased competitive pressures for firms over the last few decades have caused practitioners to examine the quality and magnitude of their Actions. Further, despite the growing involvement in corporate social responsibility (CSR), shadow of doubt remains as to whether such initiatives could potentially lead to firm's better performance and as a source of sustained competitive advantage (Dusuki and Dar, 2005).

Since, financial performance vestiges non-negotiable for the continued existence and growth of any corporation, various scholars and practitioners have insisted that all forms of CSR activities must be aligned with the core competencies of the firm. Thus firm can make more efficient and sustainable contributions to the society along with fulfilling its economic objectives (Bruch and Walter 2005; Porter and Kramer, 2002). In today's world with fierce competition, companies find it ever more difficult to handle the pressure of various external stakeholders without social investment (Margolis and Walsh, 2003). CSR initiatives can contribute to reputations advantages such as increased trust in investors, new market opportunities and positive reactions of capital markets (Fombrun et al. 2000). As the world is integrating, the stress for improved performance has proliferated the concern of firms for developing more novel ways of defining and understanding CSR.

India in the last five years has seen the surge and phenomenal growth in various businesses. The onset of globalization and liberalization of the Indian economy over the last two decades has resulted in a shift of the corporate goals from socioeconomic focus towards increasing shareholder value to the welfare of various stakeholders. Though, the CSR still seen as merely a charitable deed in India. Further, CSR is a well established theoretical concept but there is a need to establish empirical validity of CSR so that firms can incorporate it in their strategic and other decisions and investors can also use CSR for investment decisions. It will be a good attempt to provide empirical evidence to policy makers for potential usefulness of CSR to be used as mandatory corporate activities in Indian context.

Existing literature shows that no study has been undertaken so far to the best of our knowledge which showcases Indian CSR determinants. Not just to enrich the Indian CSR literature, but to get acquainted with the sweet or sour flavor of CSR for Indian firms forms the rationale of conducting this study.

\section{LITERATURE REVIEW AND THEORETICAL FRAMEWORK}

CSR impact business or not is always an important unanswerable question which looks for its justified response. Management, politicians, academicians are trying to identify who has benefited from, and who bears the costs of, socially responsible activities and up to what extent firms will spontaneously deal with significant societal issues (Tsoutsoura, 2004). This surge of increased transparency and growing expectations of the corporate sector has conceded interest to determine the critical CSR factors. To understand the background of the proposed concept, a thorough review of the literature was performed.

\section{Conceptual Background}

Earlier, donations and charitable givings were just philanthropic activities performed by corporate. These disparate charitable initiatives were generally uncoordinated and most of the times without clear decision-criteria. This approach Dispersed philanthropy as explained by Bruch and Walter (2005) was often used in corporate donations and grounded on the personal tastes of managers or board members instead of a strategic judgment of stakeholder demands and core competencies. In order to understand the CSR dimensions, numerous studies have been conducted worldwide. Theories, approaches and definitions have been proposed to clear the concept of CSR which is also referred as a Corporate Responsibility (CR) and Corporate Social Performance (CSP), still there is a clear lack of operative definitions (Manderson, 2006). So far CSR is still fuzzy with unclear limits and debatable legitimacy (Lantos, 2001, Cramer et al. 2004). World Business Council for Sustainable Development (WBCSD) in its publication "Making Good Business Sense" by Lord Holme and Richard Watts, defined CSR as "...the continuing commitment by business to behave ethically and contribute to economic development while improving the quality of life of the workforce and their families as well as of the local community and society at large".

\section{General Perspective on CSR}

Business should proactively take care of the broader societal and environmental expectations. This notion of great debate has seemingly increased the role of strategic CSR by the business worldwide. The study by Bhattacharyya (2008) guides which CSR initiatives make strategic sense to the firm through building a CSR Strategy- Framework. CSR expenditure though gave strong impact on business operation but has significant contribution outside the business. Brammer and Millington (2005) stated that firms with higher philanthropic expenditures have better reputation that shapes the perception of stakeholders. The study of CREM (2004) identifies potential bottlenecks and dilemmas which companies may 
encounter while implementing CSR. Corporations believe that being socially responsible could create value, has a positive effect on the workforce and also encourages staff loyalty and commitment (CSM, 2003). The present study seeks to understand the CSR concept from the perspective of Indian firms.

\section{CSR Perspective on Stakeholder Relationships}

It is observed that corporations manage relationship with stakeholder groups rather than with society as a whole (Clarkson, 1995). Thus, this research requires differentiating social and stakeholder issues. Corporations consider stakeholders as vital that vary country to country. It is also assumed that stakeholders do have strong influence on overal corporate performance (Chao et al. 2007; Choi et al. 2010; Snider et al. 2003; Mishra and Suar 2010). Firms are increasing more proficient at identifying and prioritizing their stakeholders, and linking CSR programs to business and social outcomes (Knox et al. 2005).

Lindgreen et al. (2007) investigated actual CSR practices associated to five diverse stakeholder groups, and derived four different clusters of firms - managers' perceptions of the influence of CSR on performance, perceived influence of stakeholders, organizational demographics and organizational performance. Mishra and Suar (2010) examined whether CSR towards primary stakeholders influences the financial and the nonfinancial performance of Indian firms. Wood and Jones (1995) developed a stakeholder framework to review the empirical literature on CSR and financial performance. Ali et al. (2010a) identified significant factors to enhance employee's organizational commitment to enhance organizational performance by analyzing the multifaceted influence of CSR. While in Ali et al. (2010b), an investigation was focused on the relationship between awareness of CSR activities and consumer purchase intention. The present study also inquires into the stakeholder relationship from an Indian perspective.

\section{CSR Perspective on Risk and Market Opportunities}

CSR is considered as a way to realize the vision of mitigating risks and optimizing performance subsequently in today's competitive environment. The study of Bassen et al. (2006) found that the financial performance, indirect links to company risk and CSR are strongly related to risk and it appears that complete deficiency of such engagement exposes firm to unnecessary risk. CSR also found to have a synergistic effect on the market orientation of business and CSR moderates the association between customer orientation and business (Brik et al. 2010). CSR is a strategic move (Heslin and Ochoa, 2008; Goss and Roberts, 2007) of firms to achieve corporate objectives if not carefully implemented, may harm the competitive advantage (Dentchev, 2004). In context with competitive advantage, several attempts have been made to investigate the CSR (Ji-Ming and Hao-Bai, 2007; Joshi et al. 2007; Kobori et al. 2009; Marín et al. 2009). Melo and Galán (2009) assessed the impact of CSR on brand value and confirmed that CSR is a valid source of intangible competitive advantage. Firms have a greater chance of sustaining over time if they have a relatively good reputation and better reputations demonstrate greater profit persistence (Roberts and Dowling, 2002). Corporate reputation generated from CSR, is an important strategic asset that contributes to firm-level persistent profitability (Roberts and Dowling, 2002). The study of Muruganantham (2010) examined a case of MNC's from India by focusing on how CSR remains a relevant strategic marketing tool, and firms use CSR to enhance the image, generate brand equity, and increase employee loyalty. The study also highlights how these firms are integrating CSR into their marketing strategy to build and sustain a competitive advantage. The present study throws light on the sustainable competitive advantage expected from CSR in Indian context.

\section{CSR Perspective on Financial Growth}

CSR is constantly linked to enhancing corporate performance from generating strong and positive reputation, brand value, retaining expert workforce etc. as intangible benefits in the long run. Various dimensions of CSR have been examined worldwide to assess the important factors of financial growth. Aupperle et al. (1985) examined the relationship between CSR and Profitability while Blazovich and Smith (2010) explored the relationship between ethical corporate citizenship and financial performance (i.e., greater profitability and efficiency, and lower cost of capital). Similarly Bouquet and Deutsch (2008) examined the way CSR affects a firm's capacity to attain profitable sales. Ghoul et al. (2010) found that firms with better CSR scores exhibit cheaper equity financing while examining the effect of CSR on the cost of equity capital. Goukasian and Whitney (2008) observed that CSR firms "outperform" their rivals in satisfying their stakeholder needs and may generate even higher returns for their shareholders in the future and moreover bearing the cost of socially responsible behavior does not have a negative trade off. Webb (2005) also documented positive causal relationship between leverage and certain CSR measures and a lower cost of debt financing for firms with strong levels of CSR. Study of Bedi (2009) reported a positive relationship between CSR expenditure and financial performance on Indian firms.

\section{RATIONALE}

In India, research is mostly confined to nature and characteristics of CSR (Arora and Puranik, 2004; Sood and Arora, 2006; Lee, 2010; Singh 2010; Srivastava and Sahay, 1995), policies and practices of CSR (Gupta and Saxena, 2006; Pradhan and Ranjan 2010; Muruganantham, 2010; Arora and Rana 2010), ethics in marketing (Krishnan and Balachandran (2004), Corporate Governance (Singhania, 2011; Sinha, 2009), competitive advantage from CSR (Sen, 2006; Joshi et al. 2007; Bhattacharyya, 2008), financial performance (Mishra and Suar 2010; Mittal et al. 2008) and various published reports on CSR (CSM, 2001; CSM, 2003). 


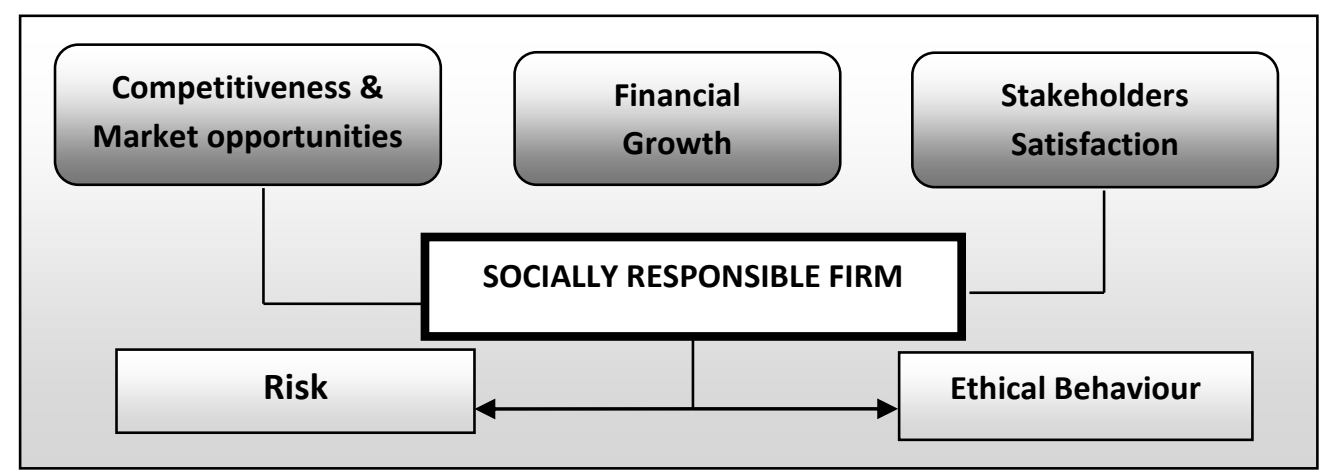

Figure 1 - Conceptual Model

Overall literature review highlights that most of the studies have dealt with developed nations while a very few studies have investigated developing economies. Only a few studies explored practical CSR approach in Indian relevance. Thus, this shows that there exists a gap in the literature and forms the basis of conducting the present study in relation to India. Further, there is a lack of studies which identify important CSR determinants or factors critical in shaping strategic decision making of corporations. This study intends to fill the gap through extending the previous work and rationalize an exploratory study to determine the critical CSR index or factors for guiding firms in line with the conceptual model of the study (Figure 1).

\section{RESEARCH OBJECTIVES AND HYPOTHESIS}

The present study determines important key factors of CSR for Indian business by inquiring into Indian firms' perspective on various CSR dimensions. The study attempts to understand the general realization and knowledge of various stakeholders about the socially responsible behavior of their firms.

H1- Indian firms are more inclined towards Socially Responsible Practices

As the stakeholder relationship come up a vital fact of the business world, the study intends to understand the viewpoint of business firms about prioritizing and maintaining the relationships with their stakeholders.

H2- $\quad$ For Indian firms CSR may positively influence the relationships with their stakeholders

As the ongoing debate on the CSR contribution to increase financial performance and competitiveness has grown deeper, the present study seeks to know the rationale about adopting CSR and its confidence with enhanced financial performance and competitiveness from the point of view of Indian firms.

H3- $\quad$ For Indian firms, adoption of CSR would have a positive impact on their financial performance.

H4- $\quad$ For Indian firms, adoption of CSR would have a positive impact on their competitiveness.

\section{SAMPLE SIZE}

The only criterion to select the firms was that the firm should be listed on S\&P ESG 500 India index for all the years since the inception of the index i.e. 2005 in the year when the survey was conducted i.e. 2009. 253 firms were targeted as sample though it was considered that the target population was very small and conducting pilot and main study separately would not be possible. Hence survey was conducted using pre-testing of the questionnaire with experts and important changes were incorporated after useful discussion. The survey received 138 total responses out of 253 mails sent with a response rate of $55 \%$ while 36 responses were dropped due to insufficient information. Refer Annexure 1 for the list of surveyed sample Indian firms.

\section{DATA SOURCE}

Both primary and secondary sources of data have been used and a survey questionnaire was designed for primary data collection to measure the extent to which a firm ideology emphasizes on socially responsible behavior. A questionnaire was focused on the financial and social performance, stakeholder relationship and creation of competitive value. To strengthen the results, secondary data sources such as websites of companies, their annual reports, newsletters, publications, and other relevant documents were also analyzed.

\section{Development of Survey Questionnaire}

A questionnaire was segmented into five sections and a total of 50 opinion base statements were designed along with 6 different questions (Table 1) using five point Likert's scales (Table 2). Detailed attention was laid on drafting statements to keep it simple and short, positively phrased and neutral to avoid any bias. The questionnaire is given in Annexure 2.

Table 1 - Questionnaire Structure

\begin{tabular}{|c|c|c|c|c|}
\hline Section & Code & Section Name & No. of Questions & Scale used \\
\hline A & ECR & Evaluating perspective on CSR & 13 & Likert \\
\hline
\end{tabular}




\begin{tabular}{|c|c|l|c|c|}
\hline B & STK & Evaluating Perspective on Stakeholder Relationships & 11 & Likert \\
\hline C & RMO & Evaluating perspective on Risk and Market Opportunities & 11 & Likert \\
\hline D & FG & Evaluating perspective on Financial Growth from CSR & 15 & Likert \\
\hline E & GCR & General Organizational CSR & 7 & Multiple \\
\hline
\end{tabular}

Table 2 - Numerical Code for Questions

\begin{tabular}{|l|c|c|c|c|c|}
\hline Scale & Strongly Agree & Agree & Neutral & Disagree & Strongly Disagree \\
\hline Numerical Code & 5 & 4 & 3 & 2 & 1 \\
\hline
\end{tabular}

\section{RESEARCH METHODOLOGY}

The study employed Descriptive Statistics, Factor Analysis, Reliability Test and ANOVA for data analysis using the SPSS 12 statistical software.

Factor Analysis identifies underlying variables, or factors, that explain the pattern of correlation within a set of observed variables. Due to small sample size, factor analysis was done in two stages. In the first stage, factor analysis was run on the four individual sections-Section $A, B, C$ and $D$ and factors were identified for each individual section. These identified factors from individual sections were then combined and factor analysis was run on the combined factors and final factors were identified. Before Principal Component Factor (PCF) analysis, as a prerequisite, Kaiser -Mayer-Olkin (KMO ) and Bartlett's test of sphericity were applied. The obtained factors were rotated to get a factor solution and extracted factors were then tested for reliability using Cronbach's alpha. The factors are then interpreted in order to provide the best explanation for the variables influenced by that factor. The methodology has been used as a guiding principle and not as a cutoff approach to overcome practical difficulties in the factor analysis.

- A cutoff value of 0.00001 for the determinant of the correlation was taken as acceptable to carry out KMO and Bartlett's test of Sphericity, necessary to conduct before PCF analysis. KMO value greater than 0.5 and Bartlett's value less than 0.05 was taken as accepted. Any variable that has significant low value (below 0.5 ) in anti image correlation Matrix were dropped before conducting PCF.

- $\quad$ Eigen Value $=$ or $>1$ is taken as cut off for extracting the number of factors and is validated by Scree plot. Rotated Component Matrix (RCM) was drawn using Varimax methods to minimize the number of variables that have high loading on each other. Factor loading of 0.3 or more is taken as significant cut-off value and Variables having a factor loading of 0.6 or more were selected. Latent variables which had a factor loading of 0.5 or above on one factor and 0.3 or more on another factor were also selected.

- In each group of variables, there are few reverse phased items that may show negative factor loading values. These items have been re-phrased to compute descriptive statistics and Cronbach Alpha value.

Reliability Test was conducted on the extracted factor to calculate a number of commonly used measures on a scale of reliability and also to provide information about the relationship between individual items in the scale. Nunnaly (1978) had indicated Cronbach's Alpha value greater than 0.7 is acceptable for reliability but lower thresholds are sometimes used in literature to manage the practical difficulties.

One way ANOVA produces a one way analysis of variance for the quantitative dependent variable by a single factor (independent) variable. The present study used it to test the hypothesis that several means are equal at significance level $(p<0.05)$ that would reconfirm the applicability of the final results of the factor and reliability analysis on various segments of respondents.

\section{RESULTS AND DISCUSSION}

\section{Quantitative Data Analysis and Interpretation}

As already described, a questionnaire was focused to identify the extent of the relationship (if any) between the variables under 5 broad heads namely, CSR, Stakeholder Relationships, Risk and Market Opportunities, Financial growth and General Organizational CSR. As expected, the survey has provided novel understanding of the concept from the organizational point of view as well as importantly enabled to identify factors of CSR vital to Indian firms.

\section{Respondents Demographics}

For drawing the demographics of respondents, content analysis was conducted to strengthen the results. $35 \%$ of respondents indicate that their job profile relates to CSR/HR while 19\% respondents were Corporate Strategist. On an average, the respondents have 16.1 years of total work experience (SD = 10.1 years). Results show that out of 102 responses, $87 \%$ respondents were male that evidenced low level of woman empowerment in India.

Table 3 - Respondent Demographics

\begin{tabular}{|l|l|l|}
\hline Demographic Variable & Number & Percentage \\
\hline Level of Designation & \\
\hline
\end{tabular}




\begin{tabular}{|c|c|c|c|}
\hline & Upper management & 31 & $30 \%$ \\
\hline & Middle management & 35 & $34 \%$ \\
\hline & Lower management & 35 & $34 \%$ \\
\hline & Missing & 1 & $1 \%$ \\
\hline & $\mathrm{N}=$ & 102 & $100 \%$ \\
\hline \multicolumn{4}{|c|}{ Total Experience } \\
\hline & Less than 5 years & 12 & $12 \%$ \\
\hline & From 5 years to 10 years & 19 & $19 \%$ \\
\hline & From 10 years to 15 years & 16 & $16 \%$ \\
\hline & From 15 years to 20 years & 21 & $21 \%$ \\
\hline & More than 20 years & 34 & $33 \%$ \\
\hline & $\mathrm{N}=$ & 102 & $100 \%$ \\
\hline \multicolumn{4}{|c|}{ CSR related Designation } \\
\hline & CSR / HR & 36 & $35 \%$ \\
\hline & Corporate Strategy \& Planning & 19 & $19 \%$ \\
\hline & $\begin{array}{ll} & \text { Others }\end{array}$ & 38 & $37 \%$ \\
\hline & Missing & 9 & $9 \%$ \\
\hline & $\mathrm{N}=$ & 102 & $100 \%$ \\
\hline \multicolumn{4}{|c|}{ Gender } \\
\hline & Male & 89 & $87 \%$ \\
\hline & Female & 13 & $13 \%$ \\
\hline & $\mathrm{N}=$ & 102 & $100 \%$ \\
\hline \multicolumn{4}{|l|}{ Age } \\
\hline & 30 years old or younger & 18 & $18 \%$ \\
\hline & Older than 30 years old, but not more than 40 years old & 35 & $34 \%$ \\
\hline & Older than 40 years old, but not more than 50 years old & 31 & $30 \%$ \\
\hline & More than 50 years old & 18 & $18 \%$ \\
\hline & $\mathrm{N}=$ & 102 & $100 \%$ \\
\hline
\end{tabular}

\section{Organization Demographics}

Table 4 indicates a variety of organizations in the sample, with $21 \%$ in Energy Power and Natural Gas (EPNG) and $15 \%$ from High Tech Industries as major respondents. The products that the organizations offer are physical goods $(62.0 \%)$, services $(27 \%)$, and physical goods combined with services $(11 \%)$. Indian culture and ethics are considered as roots in Indian business and this was aptly supported by the fact that most respondents had a deep CSR legacy (36\% respondent firms were 50 to 100 years old and $35 \%$ were 25 to 50 years old).

Table 4 - Organization Demographics

\begin{tabular}{|l|c|c|}
\hline Demographic or Performance Outcome Variable (N=102 Firms) & Number & Percentage \\
\hline INDUSTRY & 12 & $12 \%$ \\
\hline Industrials & 9 & $9 \%$ \\
\hline Metal \& Mining & 10 & $10 \%$ \\
\hline FIG & 6 & $6 \%$ \\
\hline Textile & 21 & $21 \%$ \\
\hline EPNG & 15 & $15 \%$ \\
\hline High Tech & 7 & $7 \%$ \\
\hline Automobiles & 11 & $11 \%$ \\
\hline Pharmaceuticals & 6 & $6 \%$ \\
\hline Miscellaneous & 5 & $5 \%$ \\
\hline Consumer goods & & \\
\hline TYPES OF PRODUCTS & \multicolumn{2}{|l|}{} \\
\hline
\end{tabular}




\begin{tabular}{|c|c|c|}
\hline Physical goods & 63 & $62 \%$ \\
\hline Services & 28 & $27 \%$ \\
\hline Both physical goods and services & 11 & $11 \%$ \\
\hline \multicolumn{3}{|l|}{ ESTABLISHMENT OF ORGANIZATION } \\
\hline$<25$ years old & 15 & $15 \%$ \\
\hline$>=25$ to $<50$ & 36 & $35 \%$ \\
\hline$>=50$ to $<100$ & 37 & $36 \%$ \\
\hline$>=100$ & 14 & $14 \%$ \\
\hline \multicolumn{3}{|l|}{ NUMBER OF EMPLOYEES } \\
\hline Less than 1000 & 10 & $10 \%$ \\
\hline $1000-5000$ & 22 & $22 \%$ \\
\hline $5000-10000$ & 28 & $27 \%$ \\
\hline $10000-20000$ & 33 & $32 \%$ \\
\hline 20000 or more & 9 & $9 \%$ \\
\hline \multicolumn{3}{|l|}{ CSR PROFILE } \\
\hline \multicolumn{3}{|l|}{ Years gap from the establishment of firm to initiate CSR initiatives } \\
\hline$<10$ & 28 & $27 \%$ \\
\hline$>=10$ but 30 & 31 & $30 \%$ \\
\hline$>=30$ but $<50$ & 16 & $16 \%$ \\
\hline$>=50$ but $<70$ & 7 & $7 \%$ \\
\hline$>=70$ & 10 & $10 \%$ \\
\hline Not Available & 10 & $10 \%$ \\
\hline \multicolumn{3}{|l|}{ Years served with socially responsible activities } \\
\hline$<10$ & 25 & $25 \%$ \\
\hline$>=10$ but 30 & 35 & $34 \%$ \\
\hline$>=30$ but $<50$ & 16 & $16 \%$ \\
\hline$>=50$ but $<70$ & 9 & $9 \%$ \\
\hline$>=70$ & 7 & $7 \%$ \\
\hline Missing & 10 & $10 \%$ \\
\hline \multicolumn{3}{|l|}{ Firms Disclosures } \\
\hline Publishes Separate CSR/Sustainability Reports & 72 & $71 \%$ \\
\hline Partially Mentions about their CSR activities in their annual reports & 16 & $16 \%$ \\
\hline Don't Publish any document & 14 & $14 \%$ \\
\hline
\end{tabular}

Firms with 10,000-20,000 employees were major respondents (32\%) while 27\% firms had 5,000 to 10,000 employees and $22 \%$ firms had 1000-5000 employees. As indicated in Table 4, 30\% of the Indian organizations commenced CSR activities between 10 to 30 years of their establishment while $27 \%$ of the firms started CSR activities within 10 years of their business commencement.

\section{Results From Factor Analysis}

In the first stage Factor analysis was conducted on four individual sections. 13 questions or variables from section $\mathrm{A}, 11$ from section $B, 11$ from section $C$ and 15 from section $D$ were analyzed. The mean value of all the variables is greater than 3 except for RMO1, Coefficient of correlation was less than 0.5 hence; none of the variable was dropped as no multicollineraity observed. The Correlation Matrix of all sections has determinant greater than 0.00001 . Of all the sections, KMO value was greater than 0.5 and Bartlett's values was less than 0.05 which is acceptable to conduct Principal Component Analysis. The number of factors was determined by cutoff eigenvalues $=$ or $>1$ for all the sections. Based on the results of Rotated Components Matrix and Component Transformation Matrix, best combination of variables from each section was identified. Table 5 shows identified variables and factor names along with a variable description for each factor. It is to be noted that variables having low factor loading from cutoff value, were also included in the combination which show greater significance in representing the section.

Table 5 - Identified Variables and Factors

\begin{tabular}{|c|l|c|c|}
\hline $\begin{array}{c}\text { Factor } \\
\text { Name }\end{array}$ & \multicolumn{1}{|c|}{ Factor Description } & $\begin{array}{c}\text { Number of } \\
\text { variables }\end{array}$ & \multicolumn{1}{c|}{ Variable Codes $^{\star}$} \\
\hline F1 & $\begin{array}{l}\text { Ethical and Transparent practices are } \\
\text { keys to Competitive Advantage }\end{array}$ & 6 & $\begin{array}{l}\text { ECR7 (.777), ECR10 (.712), ECR9 (.686), } \\
\text { ECR6 (.651), ECR8 (.595), ECR4 (.563) }\end{array}$ \\
\hline
\end{tabular}




\begin{tabular}{|c|l|c|l|}
\hline F2 & Securing Relationships with Stakeholders & 5 & $\begin{array}{l}\text { STK4 (.783), STK11 (.703), STK5 (.702), } \\
\text { STK10 (.509), STK7 (.456) }\end{array}$ \\
\hline F3 & $\begin{array}{l}\text { Minimizing Risk and Maximizing } \\
\text { Opportunities }\end{array}$ & 4 & $\begin{array}{l}\text { RMO8 (.849), RMO7(.712), RMO3 (.603), } \\
\text { RMO4 (.534) }\end{array}$ \\
\hline F4 & Enhancing Financial Performance & 3 & FG5 (.783), FG4 (.753),FG2 (.732), \\
\hline
\end{tabular}

*Values in brackets are Factor Loading in decreasing order

In the second stage, combined factor analysis was conducted on all 18 variables of four factors (See Table 5). The mean value of all the 18 variables was greater than 3 (Table 6 ) and coefficient of correlation for every variable was less than 0.5 . The determinant of Correlation Matrix was 0.001 , KMO value was 0.750 and Bartlett's Test significance value was 0.000 and hence acceptable to perform PCF.

Table 6 - Descriptive Statistics \& RCM of 18 Variables

\begin{tabular}{|c|c|c|c|c|c|c|c|c|}
\hline \multicolumn{3}{|c|}{ Descriptive Statistics } & \multicolumn{6}{|c|}{ Rotated Component Matrix } \\
\hline Variable Code & Mean & Std. Deviation & Variable Code & 1 & 2 & 3 & 4 & 5 \\
\hline ECR4 & 3.72 & 1.093 & FG2 & .845 & & & & \\
\hline ECR6 & 3.94 & 1.225 & FG4 & .709 & & & & \\
\hline ECR7 & 4.09 & 1.135 & FG5 & .666 & & & & \\
\hline ECR8 & 4.01 & 1.112 & RMO7 & .593 & & & & \\
\hline ECR9 & 3.56 & 1.317 & RMO8 & .584 & & & & \\
\hline ECR10 & 3.73 & 1.091 & RMO3 & .550 & & & & \\
\hline STK4 & 4.08 & 1.123 & ECR4 & & .746 & & & \\
\hline STK5 & 4.01 & 1.331 & STK10 & & .660 & & & \\
\hline STK7 & 4.20 & 1.161 & ECR9 & & .645 & & & \\
\hline STK10 & 3.72 & 1.093 & ECR6 & & .597 & & & \\
\hline STK11 & 3.73 & 1.136 & ECR7 & & .501 & & & \\
\hline RMO3 & 3.43 & 1.121 & ECR8 & & & .748 & & \\
\hline RMO4 & 3.39 & 1.204 & RMO4 & & & .743 & & \\
\hline RMO7 & 3.27 & 1.064 & ECR10 & & & .634 & & \\
\hline RMO8 & 3.47 & 1.216 & STK7 & & & 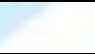 & .833 & \\
\hline FG2 & 3.19 & 1.192 & STK4 & P & & & .754 & \\
\hline FG4 & 3.23 & 1.297 & STK5 & & & & 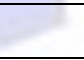 & .760 \\
\hline FG5 & 3.31 & 1.274 & STK11 & 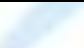 & & & & .517 \\
\hline
\end{tabular}

The number of factors was determined by cutoff eigenvalues $=$ or $>1$ which resulted in 5 components (Table 6). The descriptions of final variables for Combined Study Factor (CSF) are given in Table 7 with Cronbach Alpha value ranging from 0.505 to 0.787 . To further strengthen the results, the Cronbach alpha value of all 18 variables was also calculated which showed a value of 0.8085 which is more than 0.5 and proves that the combination is excellent and acceptable.

Table 7 - Final Combined Study Factors with Cronbach Alpha Value

\begin{tabular}{|c|l|c|}
\hline $\begin{array}{c}\text { Factor } \\
\text { Name }\end{array}$ & \multicolumn{1}{|c|}{ Description } & $\begin{array}{c}\text { Alpha } \\
\text { Value }\end{array}$ \\
\hline CSF1 & $\begin{array}{l}\text { Social Responsibility helps in improving Financial growth, exploring new markets and business } \\
\text { opportunities }\end{array}$ & 0.7878 \\
\hline CSF2 & CSR offers firms to gain competitive advantage in and out of the firm & 0.7572 \\
\hline CSF3 & CSR is a sustainable business strategy towards minimum risk & 0.6901 \\
\hline CSF4 & Realizing and answering to Stakeholder's requirement may improve firm's productivity & 0.6569 \\
\hline CSF5 & Fair business practices strengthen the trust of stakeholders & 0.5052 \\
\hline
\end{tabular}




\section{Testing the Universal Applicability of Combined Factors}

For identifying the determinants of CSR for Indian firms in holistic manners, it is important to test the universal applicability of the identified final factors. ANOVA (for more than two samples) was used to measure any significant difference in response of the segmented groups of respondents at significant value $p<0.05$ on following segments:

Experience

Less than 10 Years; 10 to 20 Years; 20 and Above

Organizational Size

No. of Employees less than 5000; 5000 to 12,000; 12,000 and Above

Results on segmented 'Total Experience' at 95\% confidence level on the five factors shows that all $p$ values were greater than 0.05 indicating there is no significant difference between the Experience profile and different factor scores however Results on segmented 'Organizational Size' shows that all $p$ values except for Combined Study Factor 2 - Competitive Advantage (0.030) were greater than 0.05 indicating there is no significant difference between the Size profile and different factor scores.

\section{Qualitative Data Analysis and Interpretation - Section E}

In addition to the quantitative data, qualitative data is important to understand the perspective. The section $E$ in the questionnaire General Organizational CSR (GCR) deals with the various questions (GCR1 to GCR6) aim to some extent, to understand the ideology, perception of respondents and different level of organizational maturity towards ethical practices. The section has used various scales as multi-answer multi choice questions, single answer-multi choice questions, and open ended questions.

As for Indian firms, CSR is not really a new course of action. While identifying the stage of the best practice behavior of the firms, the analysis showed that 38\% respondents considered their firms as Leading in CSR practices and believed that their firm was the first mover of best CSR practices, setting an example and standards for other firms and 35\% consider themselves as CSR Follower. This reflects that overall 73\% Indian firms are practicing mature CSR and further it was also a sign of encouragement that firms are growing and accepting CSR principles into their business practices. The results also revealed the facts of the organization under the curtain of CSR. Though $32 \%$ firms believed that their CSR activities were nothing more than but 'giving something back to Society', other firms believed that CSR help in gaining competitive edge $(24 \%)$ and visibility in the market $(22 \%)$ while only $16 \%$ believed that CSR improves Financial Performance of business. The study of Shankar and Panda (2011) also indicated that Indian firms have mentioned Profitability and Growth as an important theme while associating with CSR. Firms believed that CSR is not just a charitable deed but it is a way of doing business sustainably, more ethically and to become a part of the community. It is also observed that CSR is generally used to score better on the firm's reputation and enhance brand value. Very few firms really use their core competence to benefit the community (Karmayog, 2007). According to one respondent - "our firm thinks beyond charity and feels that being responsible hits on every stakeholder and on the environment".

The analysis indicated firms are assessing their CSR performance and directions (22\%) and have CSP policy as well $(22 \%) .13 \%$ firms do indicate that they are also initiating towards assessing the impact of CSR on stakeholders. Indian firms realize that a strong CSR program is a necessity in attaining good business practices and effective growth prospects still several organizations do not possess any written policy on CSR using their core competencies to benefit the society (PIC, 2007).

As companies face themselves in the challenging environment, they are more and more aware that CSR can be of indirect economic value. Firms are investing in CSR as a strategic investment into their business strategy. The results showcased that the major focus of firms remains in providing Quality and Safety to their stakeholders as they indicated that their practices in Quality or Safety (33\%) were awarded and acknowledged. Only $24 \%$ firms were recognized in Environment/CSR which shows their dedication and severe efforts towards CSR practices, but this result is not satisfactory as this value needs to rise in order to improve the overall scenario. Indian companies are required to accept CSR as a strategic management decision and come out of the outlook of believing CSR as philanthropy and donation.

Analysis showed Society at Large (20\%) is the most important stakeholder for the firms followed by Environment (16\%), Employees (15\%) and Shareholders (14\%), Local communities (13\%), Consumers (12\%) \& Suppliers (11\%). Respondents did believe in sustainable development that cares for the expectations of all stakeholders. Firms are jointly with other organizations supporting their all stakeholders with various causes. Firms have been intensely involved with social development initiatives in the communities surrounding their facilities in different ways. Organizations are supporting NGOs (34\%) for various causes, while $28 \%$ firms own NGOs. $16 \%$ firms collaborate with Global Compact or other similar reputed organizations. According to one respondent, "their organization has a dedicated force of 250 enthusiastic employee volunteers, the company has formed a Community Development Forum which works towards mobilizing society and volunteers to make the community initiatives a success".

\section{CSR DETERMINANTS FOR INDIAN FIRMS}

Eventually, due to the factorization, the essence of the factors underwent changes. Consequently, the factors were reinterpreted. It can be advocated on the basis of this comparison that these 5 identified factors given in table 7 will play a significant role in enhancing the competitiveness, financial growth and stakeholder relationship of Indian firms through CSR. Three categories were made as per the understanding of the academic knowledge developed from the study of the long standing literature on the subject of research. The present analysis highlighted major influencing factors or keystones for Indian firms. These keystones provided thoughtful account of 18 sub-keystones which are identified as crucial factors 
in determining CSP level for organizations. Firms can assess the strategic business operations and strategic CSR decisions together while focusing on bottom line performance (Figure 2).

\section{- $\quad$ Financial Health Keystones identified are CSF1 and CSF3 \\ - $\quad$ Competency Keystone identified is CSF2 \\ - $\quad$ Stakeholder Keystones are CSF4 and CSF5}

Financial Health Keystone captured two factors CSF1 and CSF3. These factors highlighted that CSR should not be seen purely as a charitable deed or unnecessary cost, withal CSR is more than this. CSR helps firms to innovate in order to satisfy its consumers, grab market opportunity and differentiate themselves from others in an ethical way to become competent. The further CSR firm would be less damaged by negative events and would face less downside risk because of strong reputation. Corporations are confident that being responsible, they are better able to snatch the business expansion opportunities, refinance the capital structure, win market competition, lower the debt, have low cost production factors and the cost of capital, high operating leverage and easy availability of resources for raising capital. Being responsible means being judgmental towards your deeds which may ultimately lead to good public image, employee retention and motivation, better access to capital and investor relationship and can affirm in value creation.

The Competency Keystone lies in CSF2 which carries important factors addressing the issues of corporate sustainability and competitive advantage from responsible business practices. It was reported that CSR helps in generating healthy competition with ethical foundation and steers the corporations towards Transparency and Disclosures. Importantly, it specifies significant difference between organizational profile for Competency. This is quite obvious as, for different size of firms, the level of competency differs. Large firms are better able to provide great remuneration to retain expert workforce, may invest in heavy technologies, may have their own R\&D centers, may spend large amounts on Marketing and Advertising and may bear the huge CSR investments which ultimately all lead to competitive advantage. It can be said that CSR seems to be one of the ingredients for the recipe of Competitive Advantage.

Figure 2 - CSR Determinants in India

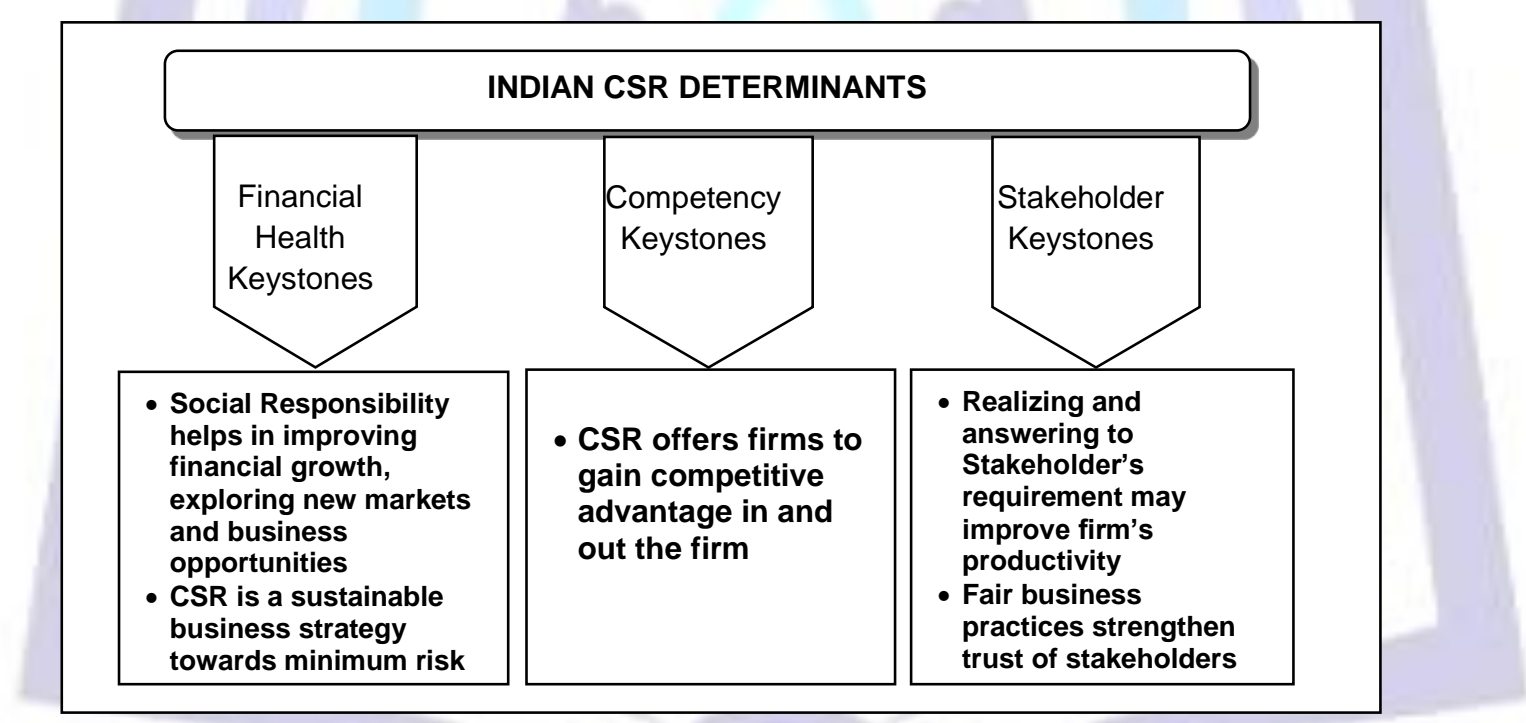

The Keystone of Stakeholders holds two factors - CSF4 and CSF5. Stakeholders constitute a major element of business operation though they have separate entities. From consumer to government, from shareholder to partner and from community to environment, everyone has its role and importance for a business from the inception. Research revealed that transparency and disclosures, open communication, health, safety and welfare are not only mandatory exercises but assists firms to improve the relationship and create a healthy competition. Firms agree that feedback, consultation, dialogues with stakeholders improves their image that may bring win-win situation for stakeholders and firms. Moreover, focusing on multi dimensional construct of CSR may serve to become a competent player in the long run.

\section{CONCLUSION}

The significant contribution of this study is the identification of business - CSR factors which would help firms to prioritize their responsible actions as well as business commitments. Indian firms are influenced by rich Indian culture and strong roots of philanthropic activities. They were engaged till today in something giving back to society from which they have taken a lot for commencing this business. But the mainstream of globalization has changed the mindset of the corporate world where giving back is not enough. This mothered the concept of strategic philanthropy or Strategic CSR. Moreover growing markets and diversified industries have made new lines of business operations in the world economic landscape.

A multi-stakeholder engagement is life-sustaining to develop sustainable business practices in any system. Today's business environment is more complex than earlier and it is expected that firms should regard the relationship with 
stakeholders at the strategic level to create value for shareholders and stakeholders. Extracted final combined factors CSF4 and CSF5 represents the importance of stakeholder relationship - responding to stakeholders through feedback, consultation, and dialogues and understanding their requirements, transparency in relations and stakeholder welfare. This approach focuses on the open communicating environment, proper health, Safety and Welfare systems that may ultimately lead to improve employee productivity and efficiency. Similarly transparency and compliance support firms to win their stakeholders. This proves that CSR may positively influence relationships with their stakeholders.

Indian CSR is typically associated with philanthropy or charity, i.e. through social contribution in education, health, sports, the environment, and other purposes. Strategists have realized the economic, financial and profitability performance towards themselves and towards society as well. Analysis revealed that a prominent and increasing number of firms are reporting to social environmental and ethical performance to their stakeholders. Moreover identified Financial Health Keystones (CSF1 and CSF3) reflects that in the long run, CSR not only strengthens the core of business, but also creates value along with cost and risk reduction and supports it in maintaining this attitude over decades. In contrast to the "immediate cost savings" in business, respondents indicated that CSR initiatives produce direct and indirect links to firm performance and further benefited from CSR opportunities. Firms also pointed that environmental, social, and governance programs may create an opportunity to generate revenues in the long run. Identifying new market opportunities and minimizing all sorts of risks from operating environment are other important factors that are influenced by CSR. As per the understanding, the corporation should consecrate concern towards multiple interconnected bottom lines such as social, environmental, market and people bottom lines instead of a single "bottom line of Profit". This proves that adoption of CSR would have a positive impact on the financial performance of firms.

Being competent or having a strong competitive advantage is nothing but a multi-dimensional excellence which is driven by sustainable business practices. CSR shifts the firm orientation to heighten its competitive advantage and form win-win state for all stakeholders. CSR is driven by Innovative Competitive Advantage through social, environmental or sustainability key drivers which help in creating novel ways of products and services, processes and market space. The analysis show Competency Keystone (CSF2) that highlighted that high growth and innovative industries may have higher performance where CSR can be utilized innovatively to distinguish product and services. Further 'Reputation' holds cost vantage for, ceteris paribus, employees are propelled to work with high-reputed firms, and thus work harder, or for lower remuneration. Research discovered that being responsible to contribute to healthy competition, ethical and transparent business practices that may indeed create good kinship in or out of the firm. Competitive Advantage is an assortment of various plans and actions not solely dependent on CSR. For attaining sustainable growth or competitive advantage, CSR can be one of the strategic elements of business. Moreover firms realize benefits from legitimacy, reputation, increased sustainable growth and shareholder value. Thus, a growing number of firms are investing substantial resources in communication with the public and becoming competitive; and believe that social and environmental issues crucial for exerting good performances especially during crisis. Analysis showed that better performed firms had a well planned, integrated CSR strategy and collaborate to better their standards, infer their customers' prospects, and keep on collecting information about the sourcing, composition and impact of their products, services and operations from their stakeholders to enhance their business processes. Thus the study verifies that adoption of CSR would have a positive impact on the competitiveness of the firms.

Qualitative data analysis revealed that respondents are aware about objectives, core values, policies and programs related to CSR initiatives brought by their individual firms. However, the response rate towards positivity of the hypothesis was quite low and was not anticipated from S\&P ESG 500 firms. The probable assumption was that their professional profile may hinder them to answer such questions. To strengthen the findings, available literature and firm level data were also reviewed. Detailed analysis uncovered that firms consider CSR practices as a noble cause and have taken CSR to next corporate level. Firms are now legitimizing their CSR ground and creating separate department, drawing plan and policies, reporting the performance and moreover assessing the impact factor of all these activities on various business dimensions. Though, this is generally considered by large scale organizations.

The respondents indicated that all this has become not only a mandatory requirement but a strategic need for the survival and sustainability and they are earnestly putting their efforts. The firm gives priority to Society and Environment in comparison with other stakeholders and implies multiple ways of support. India is no more at a nascent stage of CSR, still people see CSR just as a charitable deed. However, firms have started recognizing the vital importance of CSR in long term and acknowledging CSR into their Strategic Plans. The analysis does not demonstrate that Indian firms are more inclined towards Socially Responsible Practices as they pretend to.

\section{RECOMMENDATIONS AND CONTRIBUTION}

The survey revealed that CSR activities of many Indian companies are mainly handled by public relations or human resources department rather than a CSR department which is consistent with results of Sagar and Singla (2004). A dedicated CSR team or department should be formed to identify the core performance areas. It was also noted that respondents were unable to differentiate CSR and philanthropic activities. Firms should initiate and implement the strategic CSR into business operations and should provide training and learning to all the personnel. The response rate of CSR reporting was not high, though most of the firms are not following structured reporting on a regular basis but these are large scale firms. Intense shining projects were related to community development rather than focusing on internal practices such as corporate governance, transparency and disclosures. Hence, it is recommended to develop a sound strategy of CSR aiming at long term goals of firms with strong focus on the other key areas for equal growth. 


\section{APPENDIX}

\section{Annexure 1 - List of 102 Surveyed Firms}

\begin{tabular}{|c|c|c|c|c|c|c|c|}
\hline Sn. & NAME OF FIRM & Sn. & NAME OF FIRM & Sn. & NAME OF FIRM & Sn. & NAME OF FIRM \\
\hline 1 & $A B B$ & 27 & GlaxoSmith $\mathrm{C} \mathrm{H} \mathrm{L}$ & 53 & Kalpataru Power & 79 & Raymond \\
\hline 2 & ACC & 28 & Godfrey Phillips & 54 & Kansai Nerolac & 80 & Reliance Capital \\
\hline 3 & Adani Enterp. & 29 & Grasim Inds & 55 & Karur Vysya Bank & 81 & Reliance Inds. \\
\hline 4 & Aditya Bir. Nuv. & 30 & Greaves Cotton & 56 & Kotak Mah. Bank & 82 & Reliance Infra. \\
\hline 5 & Alfa Laval (I) & 31 & GTL & 57 & Lak. Mach. Works & 83 & Ruchi Soya Inds. \\
\hline 6 & Alok Inds. & 32 & Guj Gas Company & 58 & Larsen \& Toubro & 84 & $S A I L$ \\
\hline 7 & Apollo Tyres & 33 & Havells India & 59 & Lupin & 85 & Sesa Goa \\
\hline 8 & Arvind Ltd & 34 & HCL Infosyster & 60 & $M \& M$ & 86 & Shree Cement \\
\hline 9 & B HEL & 35 & Hero Honda Motor & 61 & MRPL & 87 & SKF India \\
\hline 10 & B P C L & 36 & Hexaware Tech. & 62 & Mastek & 88 & SRF \\
\hline 11 & Bharat Electron & 37 & Hind.Construct. & 63 & Monsanto India & 89 & Sterlite Inds. \\
\hline 12 & Carborundum Uni. & 38 & Hind.Oil Explor. & 64 & Moser Baer (I) & 90 & Tata Motors \\
\hline 13 & Chambal Fert. & 39 & Hindalco Inds. & 65 & Nava Bharat Vent & 91 & Tata Power Co. \\
\hline 14 & Cipla & 40 & IOCL & 66 & NIIT & 92 & Tata Steel \\
\hline 15 & $\mathrm{CMC}$ & 41 & ICICI Bank & 67 & NTPC & 93 & TCS \\
\hline 16 & CRISIL & 42 & $\mathrm{IFCl}$ & 68 & ONGC & 94 & Thermax \\
\hline 17 & Dabur India & 43 & India Cements & 69 & Orchid Chemicals & 95 & Thomas Cook (I) \\
\hline 18 & Deepak Fert. & 44 & IndusInd Bank & 70 & Orient Paper & 96 & Titan Inds. \\
\hline 19 & Divi's Lab. & 45 & Infotech Enterp. & 71 & Panacea Biotec & 97 & Torrent Pharma. \\
\hline 20 & Dr Reddy's Labs & 46 & ING Vysya Bank & 72 & Patni Computer & 98 & Tube Investments \\
\hline 21 & EID Parry & 47 & Ipca Labs. & 73 & Petronet LNG & 99 & United Phosp. \\
\hline 22 & Federal Bank & 48 & ITC & 74 & Pfizer & 100 & Voltas \\
\hline 23 & Finolex Cables & 49 & IVRCL & 75 & Polaris Soft. & 101 & Wipro \\
\hline 24 & Finolex Inds. & 50 & Jain Irrigation & 76 & Praj Inds. & 102 & Wyeth \\
\hline 25 & GAIL (India) & 51 & JSL Stain. & 77 & Punjab Natl.Bank & & \\
\hline 26 & Glaxosmit Pharma & 52 & Jubilant Food. & 78 & Ranbaxy Labs. & & \\
\hline
\end{tabular}


Annexure 2 - List of 102 Surveyed Firms

Survey Questionnaire

To Assess the Relationship of Financial Performance and Competitiveness of Firms with Corporate Social Responsibility (CSR)

\section{Respondent's Profile:}

Name of Respondent:

Sex:

Age:

Years

Experience

Years

Months

Total Experience:

Years

Months

Current Organization:

Organization's Profile:

Name of Organization:

\section{Industry Sector:}

Designation:

Department:

Head quarter's Country:

Contact Number:

E-mail:

No. of Employees:

Fax:

Mailing Address:

\section{SECTION A: Evaluating perspective on CSR}

Rate the statement: 1-Strongly Disagree 2-Disagree

3- Neutral

4- Agree

5- Strongly Agree

\begin{tabular}{|c|c|c|c|c|c|c|}
\hline ECR1 & $\begin{array}{l}\text { Leading Socially Responsible firms are generally linked with greater } \\
\text { financial performance }\end{array}$ & 1 & 2 & 3 & 4 & 5 \\
\hline ECR2 & $\begin{array}{l}\text { Firms with ample resources are generally more capable to put in } \\
\text { resources towards the Socially Responsible actions. }\end{array}$ & 1 & 2 & 3 & 4 & 5 \\
\hline ECR3 & $\begin{array}{l}\text { The good reputation of a firm has no role in sustaining a superior financial } \\
\text { performance over the time. }\end{array}$ & 1 & 2 & 3 & 4 & 5 \\
\hline ECR4 & $\begin{array}{l}\text { Firms with a higher environmental performance have also higher financial } \\
\text { performance, especially in high-growth and innovative industries }\end{array}$ & 1 & 2 & 3 & 4 & 5 \\
\hline ECR5 & $\begin{array}{l}\text { Being socially responsible is like a free Marketing tool for Improving } \\
\text { stakeholders relations and supply chain management }\end{array}$ & 1 & 2 & 3 & 4 & 5 \\
\hline ECR6 & $\begin{array}{l}\text { Being Socially Responsible is a path of healthy competition, ethical and } \\
\text { transparent business practices that help to establish a harmonious } \\
\text { relationship in or outside the firm. }\end{array}$ & 1 & 2 & 3 & 4 & 5 \\
\hline ECR7 & $\begin{array}{l}\text { There is no single 'Recipe' for attaining sustainable growth or competitive } \\
\text { advantage. CSR is one of its ingredients. }\end{array}$ & 1 & 2 & 3 & 4 & 5 \\
\hline ECR8 & $\begin{array}{l}\text { CSR can be a source of opportunity, innovation and competitive } \\
\text { advantage- much more than a cost, a constraint or a charitable deed. }\end{array}$ & 1 & 2 & 3 & 4 & 5 \\
\hline ECR9 & $\begin{array}{l}\text { To maximize Competitive advantage firms are required to be considerate } \\
\text { on formulating and implementing CSR activities. }\end{array}$ & 1 & 2 & 3 & 4 & 5 \\
\hline ECR10 & $\begin{array}{l}\text { Attitude towards CSR may not help the firms to develop strategies - more } \\
\text { sustainable and ultimately more value-creating }\end{array}$ & 1 & 2 & 3 & 4 & 5 \\
\hline ECR11 & $\begin{array}{l}\text { Firms can't improve their market positioning through strengthening } \\
\text { corporate culture by social welfare activities }\end{array}$ & 1 & 2 & 3 & 4 & 5 \\
\hline ECR12 & $\begin{array}{l}\text { Your organization possesses sufficient knowledge about the global CSR } \\
\text { firms like UNGC , PIC , GRI , CSM etc }\end{array}$ & 1 & 2 & 3 & 4 & 5 \\
\hline ECR13 & $\begin{array}{l}\text { Associating with international specialist Firms like ILO* / UNGC / PIC / GRI } \\
\text { / ISO** etc. may enhance the general visibility of the firm in the business } \\
\text { arena }\end{array}$ & 1 & 2 & 3 & 4 & 5 \\
\hline
\end{tabular}




\section{SECTION B: Evaluating Perspective on Stakeholder Relationship}

Rate the statement: 1-Strongly Disagree 2-Disagree 3- Neutral 4- Agree 5- Strongly Agree

\begin{tabular}{|c|c|c|c|c|c|c|}
\hline STK1 & $\begin{array}{l}\text { Investors attitude is not influenced positively for CSR firms while subscribing } \\
\text { their shares }\end{array}$ & 1 & 2 & 3 & 4 & 5 \\
\hline STK2 & $\begin{array}{l}\text { Socially responsible firms may enjoy Government privilege as in getting } \\
\text { financial assistance - directly or indirectly }\end{array}$ & 1 & 2 & 3 & 4 & 5 \\
\hline STK3 & Firms should sacrifice hefty profits to ensure customer brand loyalty & 1 & 2 & 3 & 4 & 5 \\
\hline STK4 & $\begin{array}{l}\text { Socially responsible firms focuses on the open communicating environment, } \\
\text { proper health, Safety and Welfare systems improve employee productivity } \\
\text { and efficiency }\end{array}$ & 1 & 2 & 3 & 4 & 5 \\
\hline STK5 & $\begin{array}{l}\text { Transparent dealings and timely compliance to commitments may lead to } \\
\text { win-win situation for firms as well as to all their stakeholders }\end{array}$ & 1 & 2 & 3 & 4 & 5 \\
\hline STK6 & $\begin{array}{l}\text { The firm's process of filing and resolving complaints of consumers, suppliers } \\
\text { or other stakeholders is not necessary to improve competitiveness of the } \\
\text { firms }\end{array}$ & 1 & 2 & 3 & 4 & 5 \\
\hline STK7 & $\begin{array}{l}\text { Getting feedback, consultation, dialogues with customers, suppliers or other } \\
\text { stakeholders of the firm are crucial to improve the overall image of the firm }\end{array}$ & 1 & 2 & 3 & 4 & 5 \\
\hline STK8 & $\begin{array}{l}\text { Socially responsible firms may not strengthen their hold on their stakeholders } \\
\text { to improve visibility and sustainability }\end{array}$ & 1 & 2 & 3 & 4 & 5 \\
\hline STK9 & $\begin{array}{l}\text { Being Socially Responsible firms don't have any advantage over terms of } \\
\text { trade or bargaining power with their stakeholders }\end{array}$ & 1 & 2 & 3 & 4 & 5 \\
\hline STK10 & $\begin{array}{l}\text { A 'Reputed' firm may also possess a cost advantage because, ceteris } \\
\text { paribus, employees prefer to work for high-reputation firms, and thus work } \\
\text { harder, or for lower remuneration. }\end{array}$ & 1 & 2 & 3 & 4 & 5 \\
\hline STK11 & $\begin{array}{l}\text { Responding to stakeholder requirements is linked to the core competence of } \\
\text { Socially Responsible firms and it ultimately leads to competitive advantage }\end{array}$ & 1 & 2 & 3 & 4 & 5 \\
\hline
\end{tabular}

\section{Rate the statement: 1-Strongly Disagree 2-Disagree $\quad$ 3- Neutral 4- Agree 5- Strongly Agree}

\begin{tabular}{|c|c|c|c|c|c|c|}
\hline RMO1 & $\begin{array}{l}\text { Financial risk profile of a firm does not have any influence on Socially } \\
\text { Responsible activities }\end{array}$ & 1 & 2 & 3 & 4 & 5 \\
\hline RMO2 & $\begin{array}{l}\text { It is rational to engage in CSR activities without any concern about the } \\
\text { availability of free cash flows to fund these activities }\end{array}$ & 1 & 2 & 3 & 4 & 5 \\
\hline RMO3 & $\begin{array}{l}\text { The potential entrance of new competitors or substitute products } \\
\text { maximizes in the sectors where socially responsible firms operate }\end{array}$ & 1 & 2 & 3 & 4 & 5 \\
\hline RMO4 & $\begin{array}{l}\text { If there are two identical companies, where the one is socially responsible } \\
\text { and the other is not, the former would have less downside risk for value } \\
\text { and meet fewer events that would be detrimental to its line of profit }\end{array}$ & 1 & 2 & 3 & 4 & 5 \\
\hline RMO5 & $\begin{array}{l}\text { Firms in a highly competitive environment work on CSR projects to gain } \\
\text { competitive advantages. }\end{array}$ & 1 & 2 & 3 & 4 & 5 \\
\hline RMO6 & $\begin{array}{l}\text { Conventional firms face less complexity in acquisitions, management } \\
\text { buyouts or going-private transactions compared to Socially Responsible } \\
\text { firms }\end{array}$ & 1 & 2 & 3 & 4 & 5 \\
\hline RMO7 & $\begin{array}{l}\text { Refinancing current capital structure with new partners goes easier for the } \\
\text { Socially Responsible firms }\end{array}$ & 1 & 2 & 3 & 4 & 5 \\
\hline RMO8 & $\begin{array}{l}\text { Being Socially responsible, it is easy to identify new business } \\
\text { opportunities and manage all market risks }\end{array}$ & 1 & 2 & 3 & 4 & 5 \\
\hline RMO9 & $\begin{array}{l}\text { Firms with high social performance tend to perceive more opportunities for } \\
\text { increased sales and new market opportunities }\end{array}$ & 1 & 2 & 3 & 4 & 5 \\
\hline RMO10 & $\begin{array}{l}\text { Firms may influence their market competitiveness through observing and } \\
\text { communicating the values of its business }\end{array}$ & 1 & 2 & 3 & 4 & 5 \\
\hline RMO11 & $\begin{array}{l}\text { Working together with the firms which address issues raised by } \\
\text { responsible entrepreneurship may not improve market visibility of firms }\end{array}$ & 1 & 2 & 3 & 4 & 5 \\
\hline
\end{tabular}




\section{SECTION D: $\quad$ Evaluating perspective on Financial Growth from CSR}

Rate the statement: 1-Strongly Disagree 2-Disagree 3- Neutral 4- Agree 5- Strongly Agree

\begin{tabular}{|c|c|c|c|c|c|c|}
\hline FG1 & $\begin{array}{l}\text { Being Socially Responsible does not facilitates easy availability of trade credits } \\
\text { and credit from other resources like bank and financial institution for the short } \\
\text { term financing of the firms }\end{array}$ & 1 & 2 & 3 & 4 & 5 \\
\hline FG2 & $\begin{array}{l}\text { Socially Responsible firms enjoy more operating leverage and low financial cost } \\
\text { due to easy availability of comparatively cheaper production factors }\end{array}$ & 1 & 2 & 3 & 4 & 5 \\
\hline FG3 & $\begin{array}{l}\text { Socially Responsible firms remain at par as conventional firms while raising } \\
\text { capital for financing growth opportunities }\end{array}$ & 1 & 2 & 3 & 4 & 5 \\
\hline FG4 & CSR firms, financial leverage remain higher due to lower cost of debt & 1 & 2 & 3 & 4 & 5 \\
\hline FG5 & $\begin{array}{l}\text { Socially responsible firms may lessen average cost of capital due to easy } \\
\text { availability of resources for raising capital }\end{array}$ & 1 & 2 & 3 & 4 & 5 \\
\hline FG6 & $\begin{array}{l}\text { Investing in socially responsible activities is kind of re-investment where firm's } \\
\text { retained earnings can be utilized. }\end{array}$ & 1 & 2 & 3 & 4 & 5 \\
\hline FG7 & $\begin{array}{l}\text { Firm's practice ethical values due to competitive pressure and focus on short term } \\
\text { profits }\end{array}$ & 1 & 2 & 3 & 4 & 5 \\
\hline FG8 & $\begin{array}{l}\text { Firms should not forgo short term gains even if it can expect better returns in the } \\
\text { long term }\end{array}$ & 1 & 2 & 3 & 4 & 5 \\
\hline FG9 & $\begin{array}{l}\text { Being Socially responsible firms don't have any influence on market shares and } \\
\text { brand loyalty being Socially Responsible }\end{array}$ & 1 & 2 & 3 & 4 & 5 \\
\hline FG10 & $\begin{array}{l}\text { The net result of CSR expenditure translate into the profitability as this } \\
\text { expenditure is an investment and not expenditure as such }\end{array}$ & 1 & 2 & 3 & 4 & 5 \\
\hline FG11 & $\begin{array}{l}\text { Ethical practices even at financial cost will enhance financial performance and } \\
\text { growth of business }\end{array}$ & 1 & 2 & 3 & 4 & 5 \\
\hline FG12 & Generally CSR expenditure is a strategic decision of firms to entitle for TAX relief & 1 & 2 & 3 & 4 & 5 \\
\hline FG13 & $\begin{array}{l}\text { Firms should not reserve any amount of profit for socially responsible activities } \\
\text { apart from dividend or retained earnings }\end{array}$ & 1 & 2 & 3 & 4 & 5 \\
\hline FG14 & $\begin{array}{l}\text { Investors may perceive higher market valuation for Socially Responsible firms } \\
\text { than conventional firms while there is no difference in the level of absolute or } \\
\text { excess market returns. }\end{array}$ & 1 & 2 & 3 & 4 & 5 \\
\hline FG15 & $\begin{array}{l}\text { Liberal participation in the Socially Responsible activities may impact the financial } \\
\text { performance and competitiveness of the business? }\end{array}$ & 1 & 2 & 3 & 4 & 5 \\
\hline
\end{tabular}

\section{SECTION E: General Organizational CSR (GCR)}

GCR1) Your Organization is a:

O CSR Leader

O CSR Follower

O CSR Newcomer

(First mover, best-practice example and sets standards for others)

(Serious follower of the CSR activities with extensive knowledge)

(Just initiated CSR activities with negligible knowledge)

CSR Believer yet not Implementer (Accepter of CSR concept and principles still to implement)

O Any Other (Please Specify):

GCR2) Main agenda of your firm's CSR initiative is:

$\square \quad$ To just giving Something Back to Society ${ }^{1}$

To gain Visibility in the market

To gain Competitive Edge

To improve Financial Performance of business (due to enhanced social acceptance)

Any Other (Please Specify):

GCR3) Does your organization:

$\square \quad$ Sets Corporate Social Performance (CSP) targets

Carries CSP policy / commitment statement

Assesses firm's CSR performance and direction

Assesses the impact on firm's stakeholders

Reports CSR performance (within the firm at AGM or to specified CSR firms like GC etc)

GCR4) Has your firm received any award or recognition in any of the following areas?

\footnotetext{
1 Partially accepted from the Study "“GIVING SOMETHING BACK"-Social Responsibility and South Asian Businesses in the United Kingdom: An Exploratory Study Published by Centre for Social Markets, October 2003
} 


\author{
Environment/CSR \\ Quality / Safety \\ Human resources \\ Finance \\ Any Other (Please specify)
}

GCR 5) Who are your important stakeholders considering firm's CSR policy?

$\square$ Consumers

$\square$ Employees

$\square$ Suppliers

$\square$ Shareholders

$\square$ Local communities

$\square$ Environment

Society at Large

Any Other (Please Specify):

GCR6) Does your firm cooperate with any of following organizations to further enhance the acceptance of CSR concept?

Have your own NGO or foundation

Supporting Various NGOs

Supporting specialised CSR organizations like GC, GRI etc

Supporting with any of the way

Any Other (Please Specify):

GCR7) ANY COMMENTS / SUGGESTIONS / FEEDBACK:

\title{
ACKNOWLEDGMENTS
}

I thank to my supervisor Dr. A.K. Sharma and my husband Vijay Agrwal whose immense support in the development of the subject research.

\section{REFERENCES}

1. Ali, I, Rehman, K Ur, Ali, SI, Yousaf, J \& Zia, M 2010a, 'Corporate social responsibility influences, employee commitment and organizational performance', African Journal of Business Management, vol. 4, no. 12, pp. 27962801.

2. Ali, I, Rehman, K Ur, Yilmaz, AK, Nazir, S \& Ali, JF 2010b, 'Effects of corporate social responsibility on consumer retention in cellular industry of Pakistan', African Journal of Business Management, vol. 4, no. 4, pp. 475-485.

3. Arora, B \& Puranik, R 2004, 'A Review of Corporate Social Responsibility in India', Journal of the Society for International Development

4. Arora, D \& Rana, GA 2010, 'Corporate and Consumer Social Responsibility: A Way for Value Based System', Proceedings of AIMS International Conference on Value-based Management, 11-13 August, viewed 29 Dec 2010 , <http://www.aims-international.org /aicvm/AICVMCD/pdf/ Valud-based\%20Management/YV144-Final.pdf>.

5. Aupperle KE, Carroll AB \& Hatfield JD 1985, 'An empirical examination of the relationship between Corporate social Responsibility and Profitability', Academy of Management Journal, vol. 28, no. 2, pp. 446-463

6. Bassen, A, Meyer, K \& Schlange, J 2006, 'The Influence of Corporate Responsibility on the Cost of Capital - An Empirical Analysis' in possession of Journal of Economic Literature, Viewed 10 January 2010, $<$ http://ssrn.com/abstract=984406>

7. Bedi, HS 2009, 'Financial Performance and Social Responsibility: Indian Scenario', Working Paper, viewed 29 December 2010, < http://ssrn.com/abstract=1496291>.

8. Bhattacharyya, SS 2008, 'Development of a CSR-Strategy-Framework', Proceedings of the conference CRRC, 7-9 September, Queen's University Belfast

9. Blazovich, JL \& Smith, M 2010,'Ethical Corporate Citizenship: Does it Pay?' in possession of Research on Professional Responsibility and Ethics in Accounting, viewed 2 February 2012, <http://ssrn.com/abstract=1125067>.

10. Bouquet, C \& Deutsch Y 2008, 'The impact of corporate social performance on a firm's multi-nationality', Journal of Business Ethics, vol. 80, no. 4, pp. 755-769

11. Brammer, S \& Millington A 2005, 'Corporate Reputation and Philanthropy: An Empirical Analysis', Journal of Business Ethics, vol. 61, pp. 29 - 44.

12. Brik, AB, Rettab, B \& Mellahi, K 2010, 'Market Orientation, Corporate Social Responsibility, and Business Performance', Journal of Business Ethics, Vol 99, no. 3, pp. 307-324,

13. Bruch, H \& Walter, F 2005, 'The Keys to Rethinking Corporate Philanthropy' MIT Sloan Management Review, vol. 47, no. 1, pp. 49-55

14. Carroll, AB 1999, 'Corporate social responsibility: Evolution of a definitional construct', Business and Society, vol. 38 , no. 3, pp. 268-295. 
15. Chao, G, Duan, W, Yuan, P, Yuan, X \& Chen, C 2007, 'The Relationship of Corporate Social Performance and Corporate Performance: a Stakeholder Theory Prospect', Proceedings of the The Sixth Wuhan International Conference on E-Business - Innovation Management Track

16. Chatterjee, Prof. S 2007, 'Do successful companies value Social Responsibility and Ethics in Marketing in India?' Proceedings of the International Marketing Conference on Marketing \& Society, Part I - Social Responsibility, Ethics \& Marketing, 8-10 April, 2007, IIMK

17. Choi, J, Kwak, Y \& Choe, C 2010, 'Corporate Social Responsibility and Corporate Financial Performance: Evidence from Korea', Australian Journal of Management, vol. 35, no. 3, pp. 291-311

18. Clarkson M 1995, 'A Stakeholder Framework for Analysing and Evaluating Corporate Social Performance', Academy of Management Review, vol. 20, no. 1, pp. 92-118

19. Cramer J, Jonker J \& van der Heijden, A 2004, 'Making Sense of Corporate Social Responsibility', Journal of Business Ethics, vol. 55, no. 2, pp. 215-22

20. CREM 2004, Corporate Social Responsibility in India, Policy and Practices of Dutch Companies, CREM-Report, Amsterdam, the Netherlands, February

21. CSM 2001, Corporate Social Responsibility: Perceptions of Indian business published by the centre for Social Markets, London/ Calcutta, July

22. CSM 2003, GIVING SOMETHING BACK- Social Responsibility And South Asian Businesses In The United Kingdom: An Exploratory Study, Centre For Social Markets,

23. Dentchev, NA 2004, 'Corporate Social Performance as a Business Strategy', Journal of Business Ethics, vo. 55, pp. 397-412.

24. Dusuki, AW \& Dar, MH 2005, ‘Does Corporate Social Responsibility Pay Off? An Empirical Examination of London, 22nd June

25. Fombrun, CJ, Gardberg, NA \& Barnett, ML 2000, 'Opportunity Platforms and Safety Nets: Corporate Citizenship and Reputational Risk', Business and Society Review, Vol. 105, Issue 1, pp. 85-106

26. Ghoul, S El, Guedhami, O, Kwok, CCY \& Mishra D 2010, 'Does Corporate Social Responsibility Affect the Cost of Capital?' proceedings of the Academy of International Business Meeting, Working Paper Series

27. Goss, A \& Roberts, GS 2007, 'The Cost of Virtue: Corporate Social Responsibility and the Cost of Debt Financing', Working Paper, York University Schulich School of Business.

28. Goukasian, L \& Whitney, LK 2008, 'Corporate Socially Responsible Firms Perform Well! Evidence from Financial and Operating Performances', Business Ethics: The Magazine of Corporate Responsibility, viewed 29 September $2010,<$ http://ssrn.com/abstract=972649 >.

29. Gupta \& Saxena 2006, 'Corporate Social Responsibility in Indian Service Organisations: An Empirical Study', Proceedings of the International Conference on 'CSR-Agendas for Asia', ICCSR, 13-14 April 2006, in Kuala Lumpur, Malaysia.

30. Guptara, Prabhu 2002, 'The Limits of Corporate Social Responsibility In India', viewed 29 September 2010 , <http://www.wissensnavigator.com/download/prabhu_guptara_india.pdf>.

31. Heslin, PA \& Ochoa, JD 2008, 'Understanding and developing strategic corporate social responsibility', Organizational Dynamics, vol. 37, no. 2, pp. 125-144.

32. Ji-Ming, Li \& Hao-Bai, Wang 2007, 'An Empirical Examination of Competitive Advantage and Corporate Social Responsibility - A Chinese Banking Industry Investigation', Proceedings of the IEEE Conference, 21-25 September, pp. 3292 - 3295

33. Joshi, M, Tiwari, SP \& Joshi, V 2007, 'Corporate Social Responsibility: Global Perspective, Competitiveness, Social Entrepreneurship \& Innovation', viewed 11 July 2011, < http://ssrn.com/abstract=999348 >

34. Karmayog 2007, 'Summary of the Karmayog Corporate Social Responsibility Ratings of the 500 largest Indian Companies', viewed 25 December 2010, < www.karmayog.org/csr >.

35. Kashyap, R, Mir, R \& Mir, A 2004, 'Corporate Social Responsibility: A Call for Multidisciplinary Inquiry', Journal of Business \& Economics Research, vol. 2, no. 7, pp. 51-58.

36. Knox, Prof. S, Maklan, S \& French, P 2005, 'Corporate Social Responsibility: Exploring Stakeholder Relationships and Programme Reporting across Leading FTSE Companies', Journal of Business Ethics, vol 61, no. $1, \mathrm{pg} 7$.

37. Kobori, AF \& Kobori, K 2009, 'Corporate Social Responsibility and A Modern Firm; CSR Leads to Competitive Advantage and Sustainable Development', Proceedings of the IFSAM VIIIth World Congress, Track 1, No-00597, viewed 10 January 2010, < http://www.ctw-congress.de/ifsam/download/track_19/pap00597_001.pdf >.

38. Krishnan, SK \& Balachandran, R 2004, 'Corporate Social Responsibility as a determinant of market success: An exploratory analysis with special reference to MNCs in emerging markets', Proceedings of the IIM K $-N A S M E I$ International Conference on 'Marketing Strategies for Emerging Markets', pp. 406-419

39. Lantos, GP 2001, 'The boundaries of strategic corporate social responsibility', Journal of Consumer Marketing, vol. 18 , no. 7, pp. 595-632

40. Lee, Sunyoung 2010, 'Corporate Social Responsibility in India - A Case Study for the Oxford-Achilles Working Group on Corporate Social Responsibility' viewed 11 July 2011, <http://www.sbs.ox.ac.uk/achilles/ downloads/research/India.pdf $>$.

41. Lindgreen, A, Swaen, V \& Johnston, WJ 2007, 'Corporate Social Responsibility: an empirical investigation of U.S. organisations', Research Memorandum

42. Manderson, AK 2006, 'Systems Based Framework to Examine the Multi-Contextual Application of the Sustainability Concept. Environment', Development and Sustainability, vol. 8, pp. 85-97.

43. Margolis, JD \& Walsh, JP 2003, 'Misery Loves Companies: Rethinking Social Initiatives by Business', Administrative Science Quarterly, vol. 268, no. 48, p.p. 268-305. 
44. Marín, L, Rubio, A \& Antonio, A 2009, 'The influence of corporate social responsibility on Competitive success- An empirical study in SMEs', Proceedings of the IFSAM VIIIth World Congress viewed 10 Jan 2011, <http://www.ctwcongress.de/ifsam/download/track_20/pap00311_001.pdf >.

45. Melo, T\& Galan, JI 2011, 'Effects of corporate social responsibility on brand value', Journal of Brand Management, vol. 18, pp. 423-437

46. Mishra, S \& Suar, D 2010, 'Does Corporate Social Responsibility Influence Firm Performance of Indian Companies?' Journal of Business Ethics, vol. 95, pp. 571-601.

47. Mittal RK, Sinha, N \& Singh, A 2008, 'Current Research Development - An Analysis of Linkage between Economic Value Added and Corporate Social Responsibility', Management Decision, vol. 46, no. 9, pp. 1437-1443

48. Muruganantham, Dr. G 2010, 'Case study on Corporate Social Responsibility of MNC's in India', proceedings of the International Trade \& Academic Research Conference (ITARC) - London

49. Nunnaly, J 1978, Psychometric Theory, New York: McGraw-Hill

50. Pachauri, RK 2004, 'The Rationale for Corporate Social Responsibility in India', The Financial Express, viewed 25 December 2010, < http://www.teriin.org/upfiles/pub/articles/art46.pdf>

51. PIC - Partners in Change 2007, 'Fourth report on Corporate Responsibility in India (2006-2007)'

52. PJC-Parliamentary Joint Committee on Corporations and Financial Services (2006), 'Corporate responsibility: Managing risk and creating value', June, Canberra.

53. Porter, ME \& Kramer, MR 2002, 'The Competitive Advantage of Corporate Philanthropy', Harvard Business Review, vol. 80, pp. 56-65.

54. Porter, ME \& Kramer, MR 2006, 'Strategy \& Society: The Link between Competitive Advantage and Corporate Social Responsibility', Harvard Business Review, vol. 84, no. 12, pp. 56-68.

55. Pradhan, S \& Ranjan, A 2010, 'Corporate Social Responsibility in Rural Development Sector: Evidences from India', School of Doctoral Studies (European Union) Journal, pp. 139-147

56. Raubenheimer, JE 2004, 'An item selection procedure to maximize scale reliability and validity', South African Journal of Industrial Psychology, vol. 30, no. 4, pp. 59-64

57. Reed, AM 2002, 'Corporate Governance Reforms In India', Journal of Business Ethics, vol. 37, pp. 249-268,

58. Roberts, PW and Dowling GR 2002, 'Corporate Reputation and Sustained Superior Financial Performance', Strategic Management Journal, 23, pp. 1077-1093

59. Sagar, P \& Singla, A 2004, 'Trust and Corporate Social Responsibility: Lessons from India', Journal of Communication Management, Vol. 8, Issue 3, pp. 282-290.

60. Sapovadia, VK 2008, 'Operational Risks in Context to Corporate Governance Practices in India', Working Paper Series viewed 25 December $2010,<$ http://ssrn.com/abstract=1142422>

61. Sen, SK 2006, 'Societal, environmental and stakeholder drivers of Competitive advantage in international firms', Ph.D. Dissertation, Asian Institute Of Technology, School Of Management, International Business, Thailand

62. Sengottuvelu, C 2006, 'Corporate Social Responsibility - What Are The Criteria For A Successful Program?-How Do You Sustain the Program?' viewed 25 December 2010, <http://www.apcadec.org.pt/pdfs/premio_maple_2006_ sengottuvelu.pdf>

63. Shankar, AN \& Panda, NM 2011, 'Corporate Social Reporting in India: An Explorative Study of CEO Messages To The Stakeholders', Zenith International Journal of Business Economics \& Management Research, Vol. 1, No. 3, PP. 26-47

64. Singh, Sweta 2010, 'Philanthropy to Corporate Social Responsibility: An Indian Perspective', Review of International Comparative Management, vol. 11, no. 5, pp. 990-1000.

65. Singhania, M 2011, 'Corporate Governance and Financial Performance in India: An Empirical Study', Social Responsibility Review, Vol. 4, pp. 44-64.

66. Sinha, Sunil 2009, 'Mainstreaming Transparency and Disclosure - S\&P ESG India Index', proceedings of the National conference, CRISIL Ltd, viewed 25 November <http://www.sustainabledevelopment.in/events/National-Conference/Sunil-Sinha.pdf>

67. Snider, J, Hill, RP \& Martin, D 2003, 'Corporate Social Responsibility in the 21st Century: A View from the World's Most Successful Firms', Journal of Business Ethics, 48, pp. 175-187.

68. Sood, A \& Arora, B 2006, 'The Political Economy of Corporate Responsibility in India', Technology, Business and Society, (18), United Nations Research Institute for Social Development (UNRISD) Program Paper, Geneva

69. Srivastava, V \& Sahay, A 1995, 'The Evolutionary Journey of CSR', viewed 29 December 2010, <http://www.iitk.ac.in/infocell/announce/convention/papers/Industrial\%20Economics,\%20Environment,\%20CSR-06Vivek\%20Srivastava,\%20\%20Arun\%20Sahay.pdf>

70. Stevens, J 1986, 'Applied multivariate statistics for the social sciences', Hillsdale, NJ: Lawrence, Erlbaum Associates

71. TERI 2001, 'Understanding and Encouraging Corporate Social Responsibility in South Asia', Altered Images the 2001 state of corporate responsibility in India poll, pp. 11, viewed 25 December 2010, <http://www.terieurope.org/docs/CSR-India.pdf>

72. Tsoutsoura, M 2004, 'Corporate Social Responsibility and Financial Performance', in possession of Center for Responsible Business, Working Paper Series, Paper 7, University of California, Berkeley.

73. Wikipedia, viewed 29 December 2010, <http://en.m.wikipedia.org/wiki/Principal_component_analysis>

74. Webb, E 2005, 'Agency Costs, Leverage, and Corporate Social Responsibility-A Test of Causality', Financial Decisions, Article 1.

75. Wood, D \& Jones, R 1995, 'Stakeholder mismatching: A theoretical problem in empirical research on corporate social performance', International Journal of Organizational Analysis, vol. 3, pp. 229-267. 


\section{Author' biography}

Dr. Rupal Tyagi is the Research Scholar at the Department of Management Studies, Indian Institute of Technology Roorkee, Roorkee (Uttarakhand) India. at present, she leads the CSR Intelligence Unit at CSR India Management Services LLP, India which is engaged in conducting primary and secondary research on CSR practices in Indian industry. She holds a Master's in Business Administration Degree and a Diploma in Computer Application. She is also a South Asia chapter coordinator of the Ecoblogs that is a healthy blog community to promote wise use of natural resources through public outreach conservation education program. 